\title{
Research on the Typical Modes of China's Rural Land Management Right Stock Cooperative
}

\author{
Wenli Deng \\ School of Public Administration \\ School of Marxism \\ University of Electronic Science and technology of China \\ Chengdu, China
}

\begin{abstract}
This paper compares and analyzes the six typical modes of rural land management right stock cooperatives in China, extracts the general characteristics of rural land management right stock cooperatives, and reveals the necessary conditions for the development of rural land management right stock cooperatives.
\end{abstract}

Keywords-rural land management right stock cooperative; general characteristics; development conditions

\section{INTRODUCTION}

Since the 3rd Plenary Session of the 11th CPC Central Committee, the household contract responsibility system has been widely implemented in rural China. After 1985, the rural economy gradually faced the market, and agricultural products were increasingly commercialized and specialized. There were "specialized households" and "key households" in rural areas. The farmers' demand for market information, new technologies, production services and marketing methods of agricultural products was increasing. However, due to the small scale of household decentralization, limited funds, difficulties in collecting information, and low ability to resist risks, it is not conducive to the use of large-scale machinery and modern agricultural technology. So, farmers are in a weak position in the market competition. In order to improve the status of market negotiation and enhance the ability to resist risks, only when the decentralized farmer households unite to form cooperatives and enter the market as a whole with the strength of the organization, can they achieve the purpose of increasing income and safeguarding their legitimate rights and interests.

\section{THE CONNOTATION OF RURAL LAND MANAGEMENT RIGHT STOCK COOPERATIVE}

The rural land management right stock cooperative is a land cooperative management system in which farmers are distributed with profit from land management profit according to shares and who manage the entrusted land. On the basis of the "separation of two rights" of the household contract responsibility system, it further separates into the land contractual right and the land management right. On the premise of not changing the original land contractual relationship, it clarifies the collective ownership and stabilizes the farmer's contractual right, and activates land management right according to the principles of the joint stock system and the cooperative system. The farmers' contractual land and collective land, fund, technology and equipment and other production elements are united and uniformly quantified into shares for the organization of land stock cooperatives. Vividly speaking, it is a cooperative economic organization that changes land into stock right, change farmers into shareholders who can go in for farming and get income from dividends.

The rural land management right stock cooperative is the innovation and perfection of the agricultural management mode and the rural collective land circulation mechanism, is another important change of the rural land contract management mode, and is also an effective way to solve the "three rural" issues and realize the rural revitalization.

\section{TYPICAL MODES OF RURAL LAND MANAGEMENT RIGHT STOCK COOPERATIVES IN CHINA}

As early as the mid-1980s, the Ministry of Agriculture chose Nanhai and other places in Guangdong Province to carry out the reform experiment of the joint-stock cooperative system of rural land management rights. After the 1990s, the experiment began in the coastal cities in Guangdong, Fujian, Zhejiang, Jiangsu, Liaoning, Beijing, Sichuan and Hunan and suburbs of large cities. Some backward counties in Liaoning, such as, Liaozhong County and Tai'an County, have also implemented

From the practice of various regions in China, the rural land management rights stock cooperatives in Guangdong Nanhai, Zhejiang Wenling, Jiangsu Suzhou, Liaoning Liaozhong, Beijing Daxing and Sichuan Chongzhou were the most representative. Each region has its own characteristics in the elements of shareholding elements, equity settings, equity management, dividend distribution and organization structure. See "Table I". 
TABLE I. COMPARISON OF Six Typical Modes of Rural LAND MANAGEMENT Right Stock COOPERATIVE

\begin{tabular}{|c|c|c|c|c|c|c|}
\hline & Nanhai Mode & Wenling Mode & Suzhou Mode & Liaozhong Mode & Daxing Mode & Chongzhou Mode \\
\hline $\begin{array}{l}\text { Shareholding } \\
\text { elements }\end{array}$ & $\begin{array}{l}\text { Land and collective } \\
\text { properties }\end{array}$ & $\begin{array}{l}\text { Land and } \\
\text { collective } \\
\text { properties }\end{array}$ & $\begin{array}{l}\text { Land, collective } \\
\text { properties, fund } \\
\text { and technology }\end{array}$ & $\begin{array}{l}\text { Contracted } \begin{array}{l}\text { land, } \\
\text { mobile }\end{array} \\
\text { land, } \\
\text { and fish ponds }\end{array}$ & $\begin{array}{l}\text { Contracted land and } \\
\text { funds }\end{array}$ & Contracted land \\
\hline $\begin{array}{l}\text { Equity } \\
\text { setting }\end{array}$ & $\begin{array}{l}\text { Collective shares } \\
\text { and individual } \\
\text { shares }\end{array}$ & $\begin{array}{l}\text { Collective shares, } \\
\text { mobile shares and } \\
\text { personal shares }\end{array}$ & $\begin{array}{l}\text { Collective } \\
\text { shares and } \\
\text { individual } \\
\text { shares }\end{array}$ & $\begin{array}{l}\text { Collective shares and } \\
\text { individual shares }\end{array}$ & $\begin{array}{l}\text { Land contract and } \\
\text { management right } \\
\text { shares and cash shares }\end{array}$ & $\begin{array}{l}\text { Land contract and } \\
\text { management right } \\
\text { shares }\end{array}$ \\
\hline $\begin{array}{l}\text { Equity } \\
\text { management }\end{array}$ & $\begin{array}{l}\text { It can be } \\
\text { transferred, } \\
\text { inherited, donated } \\
\text { and mortgaged in } \\
\text { the community, but } \\
\text { it cannot be } \\
\text { withdrawn from } \\
\text { capital. }\end{array}$ & $\begin{array}{l}\text { It cannot be } \\
\text { transferred, } \\
\text { inherited, } \\
\text { mortgaged, } \\
\text { donated } \\
\text { withdrawn. }\end{array}$ & $\begin{array}{l}\text { Stock rights can } \\
\text { be presented, } \\
\text { inherited and } \\
\text { transferred. }\end{array}$ & $\begin{array}{l}\text { It can be inherited or } \\
\text { transferred between } \\
\text { shareholders. }\end{array}$ & $\begin{array}{l}\text { The land-contracted } \\
\text { management right } \\
\text { shares cannot be } \\
\text { withdrawn, mortgaged, } \\
\text { donated or transferred, } \\
\text { but can be inherited } \\
\text { according to law; the } \\
\text { cash shares can be } \\
\text { inherited, transferred or } \\
\text { donated within the } \\
\text { cooperative, but cannot } \\
\text { be withdrawn. }\end{array}$ & $\begin{array}{l}\text { Stock rights may be } \\
\text { inherited, } \\
\text { transferred or } \\
\text { mortgaged with the } \\
\text { consent of the } \\
\text { cooperative and } \\
\text { cannot be } \\
\text { withdrawn during } \\
\text { the period of the } \\
\text { agreement of the } \\
\text { stock cooperative. }\end{array}$ \\
\hline $\begin{array}{l}\text { Dividend } \\
\text { distribution }\end{array}$ & $\begin{array}{l}\text { Two ways of } \\
\text { distribution: } \\
1.40 \% \text { of the } \\
\text { annual income was } \\
\text { distributed for } \\
\text { dividends and } 60 \% \\
\text { was withdrawn and } \\
\text { retained by the } \\
\text { collective } \\
\text { economic } \\
\text { organizations. } \\
2 . \quad \text { allocation = } \\
\text { profit - expanded } \\
\text { reproduction fund - } \\
\text { welfare fund }\end{array}$ & $\begin{array}{l}\text { Two ways of } \\
\text { distribution: } \\
1.50 \% \text { of net } \\
\text { income was taken } \\
\text { as collective } \\
\text { accumulation and } \\
50 \% \text { for dividend } \\
\text { distribution. } \\
2 . \text { extracted capital } \\
\text { reserve and } \\
\text { welfare fund from } \\
\text { net income, and } \\
\text { distributed the rest } \\
\text { according shares. }\end{array}$ & $\begin{array}{l}\text { Two ways of } \\
\text { distribution: } \\
1 . \text { extracted } \\
10 \%-20 \% \text { of net } \\
\text { income as } \\
\text { reserved fund } \\
\text { and risk fund, } \\
\text { and distributed } \\
\text { the rest. } \\
2 . \text { net income } \\
\text { was allocated } \\
\text { for distribution. }\end{array}$ & $\begin{array}{l}\text { Extracted the risk fund } \\
\text { and distributed the rest } \\
\text { to shareholders once. }\end{array}$ & $\begin{array}{l}60 \% \text { of the annual net } \\
\text { income was distributed } \\
\text { for dividends and } 40 \% \\
\text { was withdrawn and } \\
\text { retained as reserved } \\
\text { fund and welfare fund. }\end{array}$ & 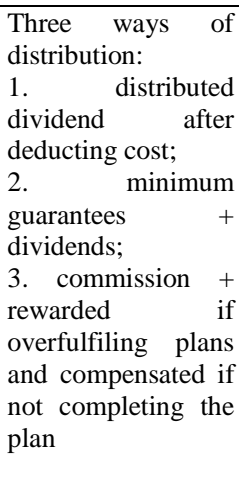 \\
\hline $\begin{array}{l}\text { Organization } \\
\text { structure }\end{array}$ & $\begin{array}{l}\text { Shareholders' } \\
\text { Congress, board of } \\
\text { directors and board } \\
\text { of supervisors }\end{array}$ & $\begin{array}{l}\text { Shareholders' } \\
\text { Congress, board of } \\
\text { directors and board } \\
\text { of supervisors }\end{array}$ & $\begin{array}{l}\text { Shareholders' } \\
\text { Congress, board } \\
\text { of directors and } \\
\text { board of } \\
\text { supervisors }\end{array}$ & $\begin{array}{l}\text { Shareholders' } \\
\text { Congress, board of } \\
\text { directors and board of } \\
\text { supervisors }\end{array}$ & $\begin{array}{l}\text { Shareholders' } \\
\text { Congress, board of } \\
\text { directors, board of } \\
\text { supervisors and stock } \\
\text { foundation }\end{array}$ & $\begin{array}{l}\text { Members } \\
\text { (representatives) } \\
\text { Congress, council } \\
\text { and board of } \\
\text { supervisors }\end{array}$ \\
\hline
\end{tabular}

\section{GENERAL CHARACTERISTICS OF RURAL LAND MANAGEMENT RightS STOCK COOPERATIVE}

Through further analysis of the six typical rural land management rights stock cooperatives formed in practice, we can reveal the general characteristics of the rural land management rights stock cooperatives in terms of property right structure, stock right structure, and governance structure and distribution mode.

\section{A. Characteristics in Property Right Structure}

The rural land management right stock cooperative is a kind of group action that many farmers take in pursuit of common interests. Like other enterprise systems, when the property right of the cooperative is divided into ownership and control right and given to a specific economic subject, the basic property right structure of the cooperative is formed.

Under this new system, the collective still owns the ownership of rural land, and the farmer households divide their contractual management rights into contractual rights and management rights, and convert the management rights into stable equity, while the actual management rights are exercised by cooperatives.
On the basis of household contract relationship, rural land management right stock cooperative redefines the property right relationship among collective, farmer household and cooperative. It solves the problem that the property right is easy to be eroded because the property right is not clear under household contract management system. It not only satisfies the need of clear property right, but also guarantees the legitimate rights and interests of the owners of property. In addition, the properties belonging to different owners can be managed jointly within a certain range, so as to achieve the purpose of improving economic efficiency.

\section{B. Characteristics in Stock Right Structure}

The shareholding objects of rural land management rights stock cooperatives are generally members of villagers' groups or administrative villages. The shareholding follows the voluntary principle. The number of shareholders is based on the land contractors in the villages.

In the equity setting, mainly use individual shares, but also appoint with a small number of collective shares, cash shares, technical shares, equipment stocks, and management stocks. Collective stock refers to the equity owned by the cooperative 
which is bought into the cooperative by appraising and discounting the collective properties used for agricultural production. Individual stocks refer to the equity owned by members of the community, generally including land contract and management rights stocks (or land resources stocks, land equity stocks, basic stocks and population stocks, etc.), property stocks (or age or labor contribution stocks) and cash stocks.

In terms of equity flows, regulations were not the same everywhere. Some places regulated that the land contract and management right shares and property shares of individual shares cannot be mortgaged, donated or transferred, but can be inherited in accordance with the law within the community. Some places regulated that they can be donated or transferred within the community. The cash shares purchased by new personnel can be inherited, transferred and donated within the scope of the community. Generally speaking, equity in rural land stock cooperatives not only has the economic functions of organizing production and deciding distribution, but also has the functions of community welfare. However, most of them were not open.

\section{Characteristics in Governance Structure}

The chairman-in-charge system is basically practiced in the rural land management rights stock cooperatives under the leadership of the shareholders' congress. The basic organizational structure of the cooperatives is composed of the shareholders' congress, the board of directors and the board of supervisors. Some large-scale cooperatives had also set up managers and marketing departments (pubic relation department), offices, agricultural machinery department, finance department and other specific functional departments specially responsible for the operation and management of the cooperatives.

The shareholders' congress is the supreme authority of the cooperative and consists of shareholders' representatives elected by all shareholders. Representatives of shareholders are produced on the basis of membership. Generally, they are allocated according to the quota and are recommended by the farmers themselves. Every few households produce a representative, whose recommendation needs to be publicized on the wall. The voting system of the shareholders' congress is one person one vote.

The board of directors elected by the shareholders' congress is the standing decision-making and management organ of the cooperative, the executive and decision-making organ entrusted by the shareholders' congress and specializing in cooperative business activities. The chairman of the board of directors is the legal representative of a cooperative, elected by secret ballot at the shareholders' congress in accordance with the provisions, and the cooperative adopts the chairmanin-charge system. Most rural land stock cooperatives have also set up a board of supervisors, which is also elected by the shareholders' congress. The daily operation and management of land joint stock cooperatives are handled by the managers appointed by the board of directors of cooperatives. In some small cooperatives, the manager is directly run by the chairman.

\section{Characteristics in Distribution Mode}

At present, there are three main forms of distribution in rural land management rights stock cooperatives: first, dividends are distributed according to profit, and the income is guaranteed at the bottom; second, the income is guaranteed at the bottom, but the profit is not divided into dividends; the most common is the third form, that is, income is guaranteed at the bottom, and profit is distributed for dividends. Profit quota $=$ the ultimate after-tax profit of a cooperative - the amount of compensation for losses - the withdrawal of statutory reserved funds and public welfare funds - the expanded reproduction fund - the welfare fund.

Adopting the income distribution method of "fixed income + floating dividend" can not only maintain the social security function of household land contract, but also greatly increase farmers' property income based on land, avoid the worries of farmers' shareholding, and improve the enthusiasm of farmers to shareholding with land management rights.

\section{CONDITIONS FOR THE DEVELOPMENT OF RURAL LAND MANAGEMENT RIGHTS STOCK COOPERATIVES}

Although the six typical rural land management rights stock cooperatives have different background, establishment time and location, their emergence and development are mostly based on several common conditions.

\section{A. Strong Support from Local Governments}

The establishment and development of the joint stock cooperative of rural land management rights cannot do without the support of the government. First of all, most farmers do not understand to buy shares through land management right, and may worry about the loss of land contract light. With low risk tolerance, they don't recognize the land management right stock cooperative highly, and even are bored about it. Therefore, the government needs to carry out extensive publicity and mobilization. Second, in the process of building the land management right stock cooperative, it involves not only the interests of the state, collective, managers and land contractors, but also the planning, development and utilization of cultivated land. The solution to these problems requires the government to issue relevant policies to regulate and guide. Third, the funds that the land management rights stock cooperative can raise are limited, and the personality quality is not high. Therefore, in order to realize the healthy development of cooperatives, the government should give some financial subsidies, financial support and tax relief, provide relevant agricultural technology and professional assistance, and give various forms of training for the internal staff of cooperatives to improve the quality of staff.

\section{B. The Relatively Developed Non-agricultural Industries \\ Enabling a Large Number of Rural Labor Force \\ Transferring into the Secondary and Tertiary Industries}

The six typical modes of rural land management rights stock cooperatives are all produced in the economically developed areas or the suburbs of large cities. The secondary and tertiary industries in these areas develop rapidly, attracting a large number of surplus rural labors. Non-agricultural income, especially wage income, has become an important source of the total income of local farmers' families. Farming 
income accounts for a relatively low proportion of household income.

Farmers already engaged in non-agricultural industries are generally reluctant to continue to operate land, resulting in a large number of lands in idle state. However, because of the security function of land, farmers will not easily give up the rights and interests of the contracted land, resulting in a strong demand for land circulation. On the one hand, by organizing cooperatives and selling management right to the cooperatives, farmers can not only retain the right of land contracting, but also obtain corresponding economic benefits by means of equity; on the other hand, cooperatives can centralize the land for unified planning and utilization, which is conducive to improving the efficiency of land use and realizing the scale efficiency of agricultural production

\section{Superior Location and Well-developed Traffic}

The geographical position and surrounding traffic conditions of the rural land management right stock cooperatives have a great influence on the operation of the cooperatives. The six typical rural land management rights stock cooperatives are superior in geographical location, located in the Pearl River Delta or the Yangtze River Delta, or located in the suburbs of large cities, with developed traffic.

Because of its advantageous geographical location and well-developed transportation, cooperatives are able to obtain timely market information, procurement channels for the means of production such as seeds, pesticides and fertilizers, and marketing channels for agricultural products. They are located in the periphery of economically developed regional central cities, and the financing needs, talent needs and technology of cooperatives could also be satisfied easily.

\section{The Relatively Strong Financial Strength, Higher Agricultural Technology Level and Management Level of Cooperatives}

Form cooperatives by means of buying into land management rights, and centralize the scattered land for unified management. On the one hand, land arrangement and development are needed; on the other hand, a variety of agricultural machinery and equipment for large-scale production need to be purchased or leased. Therefore, the cooperative shall have relatively strong financial strength.

Different from the small-scale single-family production of farmers, cooperatives concentrate the land for large-scale and specialized production, and have higher requirements for breeding, irrigation, insect control and other links, which cannot be solved by traditional agricultural production technology. Therefore, cooperative operators shall have a higher level of modern agricultural science and technology. In addition, as a form of land transfer close to the modern enterprise system, cooperatives have learned a lot from the factors of joint-stock system. The management thought of small-scale farmer economy obviously cannot guide the operation and management of cooperatives, so it is necessary for cooperative operators to have a higher level of modern management.

\section{CONCLUSION}

The report of the 18th National Congress of the Communist Party of China clearly pointed out that we should maintain and perfect the basic rural management system, develop diversified forms of scale management, cultivate new management bodies, and build a new agricultural economic system combining intensive, specialized, organized and socialized management. The land management right stock cooperative is an important part of the new agricultural production and management entity, and an innovation of the rural economic organization form. It not only protects the farmers' basic land rights and interests, but also promotes the development of agricultural industrialization and scale.

\section{REFERENCES}

[1] General Office of the Central Committee of the Communist Party of China, General Office of the State Council. Opinions on Improving the Separation of Contracted Right and Managerial Right of Rural Land Ownership. 2016

[2] Li Ning, Chen Ligen, Sun Youhai. How to Make "the Separation of Three Rights" of Farmland More Effective under the Background of Modern Agricultural Development - Research on Restraint of Subdivision of Property Rights Structure and its Organizational Governance. Agricultural Economic Issues, 2016 (7).

[3] Han Xueping. Real Right Logic for the Effective Realization of Rural Land Management Rights under the "Separation of Three Rights". Social Sciences Journal, 2016 (5)

[4] He Anhua. Land Share Cooperation Mechanism and Cooperation Stability: Comparative Analysis of Suzhou Cooperative Farm and Land Stock Cooperatives. China Rural Observation, 2015 (5).

[5] Luo Biliang, Hu Xinyan. Transformation of Agricultural Management Methods: Existing Experiments and Directions of Effort. Rural Economy, 2016 (1).

[6] Guo Xiaoming, Dong Huan. The Road to Modernization of Grain Management in Southwest China: Realistic Observation Based on Chongzhou Experience. China's Rural Economy, 2014 (7).

[7] Gao Hai, Ouyang Rengen. Legal Analysis of Interest Distribution of Farmland Shareholding Cooperatives. Chongqing Social Sciences, 2011 (1).

[8] Zhang Xiaohan. Rural Land Stock Cooperatives: Operational Characteristics, Realistic Dilemma and Selection of Solutions: A Case Study of Shanglin Village, Southern Jiangsu Province. China Land Science, 2009 (2).

[9] Ma Jian. Nanhai Mode: Innovation and Dilemma: A Survey of the Development of Land Stock cooperative System in Nanhai. Rural Work Communication, 2008 (17). 